\title{
Vitamin D deficiency in children
}

\author{
Mohd Ashraf', Mohammad Ishaq ${ }^{2}$, Nazir Ahmed Parrey ${ }^{3}$, Mohd Irshad ${ }^{2}$, Kaisar Ahmed ${ }^{4}$ \\ ${ }^{1}$ Lecturer Pediatric Nephrology, GB Pant Hospital Sonwar, J\&K, India, ${ }^{2}$ Registrar, Department of Pediatrics, GB Pant Hospital, Govt. Medical \\ College Srinagar, J\&K-India, ${ }^{3}$ Consultant Pediatrics, Department of Health, Govt of Jammu and Kashmir, ${ }^{4}$ Professor \& Head, Department of \\ Pediatrics, GB Pant Hospital, Govt. Medical College Srinagar, J\&K, India
}

\section{A B S TR A C T}

Background: Vitamin D deficiency in children is an important medical entity commonly diagnosed during early childhood. Prevalence and incidence of vitamin D deficiency in children is underestimated and can have far reaching consequences as per the latest evidence. Children at high risk should be identified and treated accordingly to avoid the treatable misadventures of future life. Aim: The purpose of this review is to provide summary of the latest research in particular to the practical aspects of vitamin D deficiency in children. Methods: A literature search in PubMed, Medline, Embase, Scopus, Google Scholar, and DOAJ was conducted, regarding pediatric vitamin $D$ deficiency related research and review articles in English language, using keywords or phrases such as bones; childhood allergy; calcium; children; diabetes mellitus type 1 ; respiratory infections; rickets; failure to thrive, $25-\mathrm{OH}$ vitamin $\mathrm{D}$. Conclusion: Despite major advances in unfolding the classical and non-classical role of vitamin $D$ in various health related events in children, yet most of the pediatric population is vitamin $D$ deficient even in countries like India with ample sunlight.

Key words: Bones, Calcium, Children, Rickets, Vitamin D deficiency
Access this article online

Website:

http://nepjol.info/index.php/AJMS

\section{INTRODUCTION}

Vitamin D refers two main compounds; vitamin D2 (ergocalciferol or calciferol), found in plants and vitamin D3 (cholecalciferol) found in animal tissues or that derived from 7-dehydrocholesterol in the skin during exposure to ultraviolet light. Besides being an important fat soluble vitamin involved in calcium and bone metabolism, its hormonally active form, $1 \alpha, 25$-dihydroxyvitamin D $\left[1 \alpha, 25(\mathrm{OH})_{2} \mathrm{D}\right.$; calcitriol $]$ has numerous important extra-skeletal effects on the cardiovascular system, central nervous system, endocrine system, and immune system in addition to cell differentiation and cell growth. ${ }^{1}$ Vitamin D manifests its diverse biological effects by binding to the vitamin D receptor (VDR) found in over 35 target tissues that are not involved in bone metabolism. ${ }^{2}$ These include endothelial cells, islet cells of the pancreas, hematopoietic cells, cardiac and skeletal muscle cells, monocytes, neurons, placental cells and T-lymphocytes. Expression of vitamin D receptor by various tissues defines its pleiotropic effects. It is because of this pleiotropism, there is renewed interest in the research on adequacy of vitamin $\mathrm{D}$ levels that appears to be relevant to the health of all ages, including fetal life. During the last decade the research has explicitly delineated the vitamin $\mathrm{D}$ deficiency among the high risk neonates, infants, children and adolescents, ${ }^{3-5}$ around the world, prompting a growing interest in redefining the vitamin $\mathrm{D}$ health related benefits and its supplementation from neonates through adolescence.

\section{PATHOPHYSIOLOGY}

Although it was the Soranus during the Roman empire (100 BC) who reported bowed legs in Roman infants and compared them with Greek infants, and Galeno during the same period classified it as rickets. ${ }^{6}$ But it was only after the outbreak of rickets verified in the 17th century in England (English disease), vitamin D deficiency emerged as hot entity. However, the chemical transformations and biological actions of active form of vitamin $\mathrm{D}$, on bone and other organs have recently been understood to a far greater degree. Main forms of vitamin D are vitamin D2, 
found in plants and vitamin D3 found in animal tissues or that derived from 7-dehydrocholesterol in the skin during exposure to ultraviolet light-B(UVB). The time needed to produce adequate vitamin $\mathrm{D}$ from the skin depends on the strength of the UVB rays, the length of time spent in the sun, and the amount of pigment in the skin. People living at geographic locations far from the equator have low Vitamin D levels, indicating the importance of duration and intensity of sunlight exposure. ${ }^{7}$ This also indicate that the dietary intake of vitamin $\mathrm{D}$ alone is frequently insufficient to sustain serum 25-hydroxyvitamin D levels even among persons hailing from well-off sections of the community, consuming food fortified with vitamin D. ${ }^{8} \mathrm{UVB}$ rays strike the skin, and convert 7-dehydrocholesterol to cholecalciferol (vitamin D3) in the skin. The vitamin D binding protein transports the vitamin $\mathrm{D} 3$ to the liver where it undergoes hydroxylation to $25(\mathrm{OH}) \mathrm{D}$ and then to the kidneys where it is hydroxylated by the enzyme $1-\alpha$ hydroxylase to its active form $1,25(\mathrm{OH})_{2}$ D. ${ }^{9}$ In kidney, this metabolic step occurs in the mitochondria of epithelial cells in the proximal nephron after the reabsorption of 25-hydroxyvitamin D together with vitamin D binding protein (DBP) from tubular fluid by a megalin-dependent mechanism. ${ }^{10}$ Calcitriol is then released into peritubular blood, where it circulates in plasma again bound to DBP. ${ }^{11}$ Calcitriol is metabolized to the inert $1,24,25(\mathrm{OH})_{3} \mathrm{D}$ through the action of the 24,25-hydroxylase enzyme (CYP24), while as vitamin $\mathrm{D} 2$ is hydroxylated to $24,25(\mathrm{OH})_{2} \mathrm{D},{ }^{12}$ thus providing the primary metabolism of the active compound. Recent studies have hown that the primary role of DBP is to maintain stable serum stores of vitamin $\mathrm{D}$ metabolites. ${ }^{13}$ In PCT both $25(\mathrm{OH}) \mathrm{D}$ and $1,25(\mathrm{OH})_{2} \mathrm{D}$ with $\mathrm{DBP}$ are endoctyosed in a megalin- mediated pathway in the kidney, ${ }^{14}$ mechanism that is also likely in other cell types. ${ }^{15}$ The renal synthesis of $1,25(\mathrm{OH})_{2} \mathrm{D}$ is regulated besides itself, by several other factors including serum phosphorus, calcium, fibroblast growth factor 23 (FGF-23), and parathyroid hormone (PTH) ${ }^{16}$ Besides the kidneys, extra renal conversion of $25(\mathrm{OH}) \mathrm{D}$ to $1,25(\mathrm{OH})_{2} \mathrm{D}$ do occur in osteoblasts, breast epithelial cells, prostate gland, alveolar and circulating macrophages, pancreatic islet cells, synovial cells, and arterial endothelial cells. ${ }^{17}$ Vitamin D deficiency may be caused by limited sunlight exposure, dietary deficiency of vitamin $\mathrm{D}$, poor absorption of vitamin $\mathrm{D}$ as a result of gastrointestinal disease, abnormalities of vitamin D metabolism, or vitamin D resistance and clinical manifestation can be classical or non-classical or both besides primary bone involvement.

\section{Serum 25(OH) D level: A vitamin D yardstick}

Calcidiol $(25(\mathrm{OH}) \mathrm{D})$ levels in blood are accepted as the standard measure of vitamin $\mathrm{D}$ levels because they correlate best with end-organ effects, the concentration of $1,25-(\mathrm{OH})_{2} \mathrm{D}$ must not be used, as it may be elevated even in severe vitamin $\mathrm{D}$ deficiency. According to latest research, the serum $25(\mathrm{OH})$ D level must be in the range of $30-100 \mathrm{ng} / \mathrm{mL}$ to avoid long-term negative health consequences; a $25(\mathrm{OH})$ $\mathrm{D}$ status between 40 to $60 \mathrm{ng} / \mathrm{mL}$ or 100 to $150 \mathrm{nmol} / \mathrm{L}$ is ideal. ${ }^{16}$ Levels between $21-29 \mathrm{ng} / \mathrm{mL}$ are designated as moderate vitamin $\mathrm{D}$ deficiency or vitamin $\mathrm{D}$ insufficiency while levels below $20 \mathrm{ng} / \mathrm{mL}$ is severe vitamin D deficiency. Vitamin $\mathrm{D}$ intoxication is only to be expected at levels of $25(\mathrm{OH}) \mathrm{D}>150 \mathrm{ng} / \mathrm{mL}^{18}$

\section{Risk and disease: Vitamin D status}

Current studies have shown vitamin D deficiency as likely etiological factor in the pathogenesis of many diseases like multiple sclerosis(MS), type 1 diabetes, inflammatory bowel disease, infections of the respiratory tract, immune deficiency, cardiovascular diseases, cancer of colon, and breast, non-Hodgkin's lymphoma and Alzheimer disease. ${ }^{19-22}$

Role of fetus and vitamin $D$ in fetal development Prevalence of vitamin D deficiency varies from $15 \%$ to $80 \%,{ }^{23,24}$ indicating lack of vibrant measures to overdue this nutritional deficiency menace. Vitamin D metabolism during pregnancy undergoes a series of adaptations as the fetus is completely dependent on placental delivery and therefore on maternal intake and production. ${ }^{25}$ Despite increase in vitamin $\mathrm{D}$ synthesis by the kidney and placenta ${ }^{26}$ $1,25(\mathrm{OH})_{2} \mathrm{D}$ is not able to cross the placenta while $25(\mathrm{OH})$ $\mathrm{D}$ enters fetal circulation and is then hydroxylated into the corresponding active form in the fetal kidney. ${ }^{27}$ Some of the studies in human subjects have shown a strong relationship between maternal and fetal circulating (cord blood) $25(\mathrm{OH})$ D concentrations. ${ }^{28}$ Although rare severe maternal vitamin $\mathrm{D}$ deficiency during pregnancy may develop rickets in utero and manifest this deficiency at birth. ${ }^{29}$ Hence adequate nutritional vitamin $\mathrm{D}$ status during pregnancy is important for fetal skeletal development, tooth enamel formation, and perhaps general fetal growth and development. ${ }^{30}$ One of the recent studies have shown an association between vitamin $\mathrm{D}$ intake during pregnancy and birth weight but not infant head circumference or length at birth. ${ }^{31}$ The importance of maternal vitamin $\mathrm{D}$ status on subsequent development of type 1 diabetes in newborns is described by a Norwegian cohort study of 20,072 women. A low maternal $25(\mathrm{OH}) \mathrm{D}$ status $(\leq 54 \mathrm{nmol} / \mathrm{L}$ or $21.6 \mathrm{ng} / \mathrm{mL})$ during pregnancy was associated with a more than 2 -fold risk increase for the development of type 1 diabetes later in life compared with a good maternal $25(\mathrm{OH}) \mathrm{D}$ status $(>89 \mathrm{nmol} / \mathrm{L}$ or $35.6 \mathrm{ng} / \mathrm{mL}) .^{32}$

\section{Role of vitamin $D$ in infants}

The vitamin D status of the lactating mother has a direct relation to the breast milk. ${ }^{29,33}$ Vitamin $\mathrm{D}$ content in breast milk ranges from $15-50 \mathrm{IU} / \mathrm{L}$ in a vitamin $\mathrm{D}-$ sufficient 
mother, and infant taking $750 \mathrm{~mL} /$ day of exclusive breastfeeding without sun exposure would provide only 11 to $38 \mathrm{IU} /$ day of vitamin D, which is far below the recommended minimum intake of $400 \mathrm{IU} /$ day. $^{34}$ Infants who are exclusively breastfed but who do not receive supplemental vitamin D or adequate sunlight exposure are at increased risk of developing vitamin $\mathrm{D}$ deficiency and/or rickets. ${ }^{35,36}$ Concern about the adequacy of human milk in providing vitamin $\mathrm{D}$ in required amounts are well discussed. ${ }^{37}$ Evidence based better understanding of the detrimental effects of insufficient vitamin D status before the appearance of rickets, American Academy of Pediatrics (AAP) has recommended a supplementation of $400 \mathrm{IU}$ of vitamin $\mathrm{D} /$ day to all exclusive breast fed/high risk infant. ${ }^{38}$

Role of vitamin D in late childhood and adolescents Vitamin D deficiency is not limited to infancy and early childhood but has been reported worldwide during the periods of accelerated growth in late childhood and adolescents. ${ }^{39-41}$ Recent studies of vitamin D status have shown that $16 \%$ to $54 \%$ of adolescents have serum $25-\mathrm{OH}-\mathrm{D}$ concentrations of $50 \mathrm{nmol} / \mathrm{L} .^{38}$

\section{Pediatric diabetes and vitamin D deficiency}

A link between the low intake of vitamin D and calcium with diabetes metabolic syndrome has been proposed in many studies. ${ }^{42-44}$ The autoimmune nature of the type 1 diabetes usually results from a $\mathrm{T}$ cell mediated destruction of insulin producing, pancreatic $\beta$-cells with a typical onset in childhood or adolescence. There is evidence that vitamin $\mathrm{D}$ supplementation early in life is a protective factor against the development of type 1 diabetes. A study from Finland involving 12058 children followed over 30 years, has showed that newborn babies who receive 2000 IU of vitamin D3 daily as rickets prophylaxis had a $88 \%$ lower risk for type 1 diabetes mellitus compared with those with lower-dosed supplementation during the first years of life, however there was variation in dose of vitamin $\mathrm{D}$ equilent given. Children who suffered from rickets in the first year of life had a 3-fold higher risk for type 1 diabetes compared with healthy children. ${ }^{45}$ In a meta-analysis of 4 case-control studies, the risk for type 1 diabetes in infants who received a vitamin $\mathrm{D}$ supplement compared with those who received no vitamin D was reduced by $29 \%$ (OR $0.71,95 \%$ CI 0.60 to 0.84$).{ }^{46}$ However, a case control study from the Egypt revealed that serum vitamin $\mathrm{D}$ levels were not significantly lower in diabetic subjects compared to the control group $(24.7 \pm 5.6$ vs $26.5 \pm 4.8 \mathrm{ng} / \mathrm{ml} ; \mathrm{p}>0.05) .{ }^{47}$

\section{Pediatric asthma and vitamin D deficiency}

A study from Thailand recruited 125 asthmatic children, did reveal, vitamin D deficiency $(<20 \mathrm{ng} / \mathrm{mL})$ in $19.2 \%$ of the patients, insufficiency $(20-30 \mathrm{ng} / \mathrm{mL})$ in $44.8 \%$, and sufficiency $(>30 \mathrm{ng} / \mathrm{mL}$ ) in $36 \%$. Study concluded that high prevalence of vitamin D deficiency and insufficiency were found in asthmatic children in Thailand; however, there was no significant relationship between vitamin D status and the level of asthma control or other asthma parameters. ${ }^{48}$ One study through questionnaires method suggested that high levels of vitamin D could be protective against allergic rhinitis and asthma in childhood..$^{49}$ However, recently conducted study has suggested that vitamin D may not be protective against food allergy, claiming that high vitamin $\mathrm{D}$ levels during pregnancy enhance the risk within the first two years of life. ${ }^{50}$

Pediatric respiratory tract infections and vitamin D deficiency

In a systematic review and meta-analysis of 11 randomized controlled trials, vitamin $\mathrm{D}$ showed a protective effect against respiratory tract infection (RTI)(OR, 0.64; 95\% CI, 0.49 to 0.84$)$. The protective effect was larger in studies using once-daily dosing compared with bolus doses $(\mathrm{OR}=0.51$ vs $\mathrm{OR}=0.86, \mathrm{p}=0.01) .{ }^{51}$ Another recent study of 18,883 persons (age $>12$ y) from USA was carried out to know the relationship between serum 25-OH-D levels and the susceptibility to infections of the upper respiratory tract in relation to the season. Vitamin D status correlated inversely with the rate of infection of the upper respiratory tract: Compared with subjects with normal $25(\mathrm{OH}) \mathrm{D}$ status $(\geq 30 \mathrm{ng} / \mathrm{mL})$, the subjects with insufficient status $(10-30 \mathrm{ng} / \mathrm{mL})$ showed a 1.24-fold increase in infection rate, while the subjects with a pronounced vitamin $\mathrm{D}$ deficiency $(<10 \mathrm{ng} / \mathrm{mL})$ showed a 1.36 -fold increase in infection rate (odds ratio [OR], 1.36; at 95\% CI). ${ }^{52}$ In another randomized double-blinded trial ${ }^{53}$ from Mongolia carried out on 247 schoolchildren, the effect of daily ingestion of vitamin D unfortified or fortified milk (fortified with $300 \mathrm{IU}$ vitamin D) was evaluated (control: $\mathrm{n}=104$; D-group: $\mathrm{n}=143$ ). Compared with controls, children receiving vitamin D reported significantly fewer acute respiratory infections (ARI) during the study period (mean: 0.80 vs. $0.45 ; \mathrm{p}=$ 0.047), with a rate ratio of 0.52 ( $95 \%$ CI: $0.31-0.89) . .^{53}$

\section{Pediatric cardiovascular system and vitamin D deficiency}

In a 16-week randomized clinical trial with normotensive black boys and girls, the relation between $25(\mathrm{OH}) \mathrm{D}$ concentrations and total body fat mass by dual-energy $\mathrm{X}$-ray absorptiometry, and the arterial stiffness measured by pulse wave velocity (PWV) in response to $2000 \mathrm{IU}$ vitamin D supplementation was analyzed. The results demonstrate that vitamin $\mathrm{D}$ supplementation may be effective in optimizing vitamin D status and counteracting the progression of aortic stiffness in black youth. Plasma $25(\mathrm{OH}) \mathrm{D}$ concentrations in response to the $2000 \mathrm{IU} / \mathrm{d}$ supplementation were negatively influenced by adiposity. ${ }^{54}$ In a placebo-controlled, double-blind study of 80 infants 
with cardiac insufficiency, infants who recieved daily supplementation of 1200 IU vitamin D3 for a period of 12 weeks had a significant improvement in the performance of the heart muscle (e.g. left ventricular ejection fraction (LVEF $\uparrow)$ and the reduction of various cardiovascular risk parameters than children in the placebo group. ${ }^{55}$

\section{ETIOLOGY OF VITAMIN D DEFICIENCY}

Latest evidence suggests that, the main source of vitamin $\mathrm{D}$ is sunlight exposure. Although other sources of vitamin $\mathrm{D}$ are plant and animal derived, but most of the vitamin $\mathrm{D}$ is obtained from exposure to sunlight and less than $10 \%$ is derived from the food born sources. ${ }^{34}$

\begin{tabular}{|c|c|}
\hline \multicolumn{2}{|c|}{ Common causes of vitamin D deficiency ${ }^{34}$} \\
\hline $\begin{array}{l}\text { Decreased vitamin } D \\
\text { synthesis }\end{array}$ & $\begin{array}{l}\text { Skin pigmentation, physical agents } \\
\text { blocking UV-B radiation (sunscreen, } \\
\text { clothing, shade and clouds) }\end{array}$ \\
\hline Geography & Latitude, season, air pollution, cloud cover \\
\hline $\begin{array}{l}\text { Decreased intake of } \\
\text { vitamin } D\end{array}$ & $\begin{array}{l}\text { Poverty and extensive exclusive } \\
\text { breastfeeding }\end{array}$ \\
\hline Malabsorption & $\begin{array}{l}\text { Celiac disease, pancreatic insufficiency, } \\
\text { biliary atresia }\end{array}$ \\
\hline $\begin{array}{l}\text { Decreased synthesis or } \\
\text { increased degradation } \\
\text { of } 25(\mathrm{OH}) \text {-D }\end{array}$ & $\begin{array}{l}\text { Chronic liver disease and drugs such as } \\
\text { rifampicin, isoniazid, anticonvulsants }\end{array}$ \\
\hline
\end{tabular}

\section{VITAMIN D CLASSIFICATION OF VITAMIN ${ }^{18,56}$}

United States Institute of Medicine (IOM) that works on behalf of the USA and Canadian governments, reviewed the data on calcium and vitamin $\mathrm{D}$ intake requirements and their roles in human health report on Dietary Reference Intakes for Calcium and Vitamin D; while the United States Endocrine Society's Clinical Practice Guideline on Evaluation, Treatment, and Prevention of Vitamin D deficiency, that have produced conflicting reports regarding the various states of vitamin $\mathrm{D}$ in humans. IOM specifies an estimated average requirement of $400 \mathrm{IU} /$ day for those with minimal or no sunlight exposure, while United States Endocrine Society's estimates that there should be three- to fivefold higher at (1500-2000 IU/day) without any specification about sunlight exposure. Summary of the vitamin D states by these authantic bodies is given as under. ${ }^{18,19}$

\begin{tabular}{|c|c|c|c|}
\hline \multicolumn{2}{|c|}{ US endocrine society } & \multicolumn{2}{|c|}{ US institute of medicine } \\
\hline $\begin{array}{l}\text { Vitamin D } \\
\text { status }\end{array}$ & $\begin{array}{l}\text { Serum } \\
\text { levels }\end{array}$ & $\begin{array}{l}\text { Vitamin D } \\
\text { status }\end{array}$ & $\begin{array}{l}\text { Serum } \\
\text { levels }\end{array}$ \\
\hline Deficiency & $<20 \mathrm{ng} / \mathrm{mL}$ & Severe deficiency & $<5 \mathrm{ng} / \mathrm{mL}$ \\
\hline Insufficiency & $21-29 \mathrm{ng} / \mathrm{mL}$ & Deficiency & $<15 \mathrm{ng} / \mathrm{mL}$ \\
\hline Sufficiency & $>30$ ng/mL & Sufficiency & $>20 \mathrm{ng} / \mathrm{mL}$ \\
\hline Toxicity & $>150$ ng/mL & Risk of toxicity & $>50 \mathrm{ng} / \mathrm{mL}$ \\
\hline
\end{tabular}

Vitamin $D$ and serum biochemistry ${ }^{57}$

\begin{tabular}{|c|c|c|c|c|c|c|}
\hline & $\begin{array}{c}25(\mathrm{OH}) \mathrm{D} \\
\mathrm{ng} / \mathrm{ml}\end{array}$ & $25(\mathrm{OH})_{2}$ & $\mathrm{Ca}$ & -1PO4) $)^{2-}$ & $\begin{array}{l}\text { Alk. } \\
\text { phos }\end{array}$ & PTH \\
\hline $\begin{array}{l}\text { Vitamin D } \\
\text { deficiency }\end{array}$ & $<20$ & $\uparrow$ & $\downarrow$ & $\downarrow$ & $\uparrow$ & $\uparrow$ \\
\hline $\begin{array}{l}\text { Vitamin D } \\
\text { insufficiency }\end{array}$ & $21-29$ & $\uparrow$ or NR & NR & NR & $\uparrow$ or NR & $\begin{array}{l}\uparrow \text { or } \\
\text { NR }\end{array}$ \\
\hline $\begin{array}{l}\text { Vitamin D } \\
\text { sufficiency }\end{array}$ & $>30$ & NR & $N R$ & NR & NR & NR \\
\hline
\end{tabular}

NR: levels within the normal range, Alk.phos.: alkaline phosphatase, PTH: parathyroid hormone, Ca: calcium, (OH) D: hydroxy vitamin D

\section{TREATMENT REGGIMENS}

In 2011 Institute of Medicine (IOM) revised recommendations favor routine daily allowance (RDA) of $600 \mathrm{IU} /$ day for ages of 1-70 years. ${ }^{19}$ While American Academy of Pediatrics (AAP) recommendrecommends $400 \mathrm{IU} /$ day of vitamin $\mathrm{D}$ for exclusively and partially breastfed infants shortly after birth, to be continued until they are weaned and consume $\geq 1,000 \mathrm{~mL} /$ day of vitamin $\mathrm{D}$ fortified formula or whole milk. Those children and adolescents who may not obtain vitamin $\mathrm{D}$ at-least $400 \mathrm{IU} /$ day from all sources should be supplemented with vitamin $\mathrm{D}^{58}$ In children short term or long term regimens, or stoss therapy have almost similar results. Similarly administration of either vitamin D2 or D3 does not have much difference to the outcome, forcing the treating clinician to individualize the treatment plan. However some studies have shown administration of D3 is 3 times more potent than D2. ${ }^{59}$ Short term administration of vitamin D2 or 2000 units daily or vitamin D2 50,000 units weekly has yielded equivalent results. ${ }^{47}$ The total dose of vitamin $\mathrm{D}$ has been reported to be more predictive of vitamin D sufficiency rather than the frequency of dosing (daily, weekly or monthly). ${ }^{60}$

\begin{tabular}{lcccc}
\hline Group & $\begin{array}{c}\text { Daily } \\
\text { regimen } \\
\text { (8-12 weeks) }\end{array}$ & $\begin{array}{c}\text { Weekly } \\
\text { regimen } \\
\text { (8-12 weeks) }\end{array}$ & $\begin{array}{c}\text { Stoss } \\
\text { therapy } \\
\text { (PO/IM) } \\
\text { (1-5 days) }\end{array}$ & Maintanance \\
\hline$<1$ mo & 1,000 & 50,000 & & $400-1,000$ \\
old & IU & IU & IU \\
$1-12$ mo & $1,000-5000$ & 50,000 & $(1-6$ lakh $)$ & $400-1,000$ \\
old & IU & IU & IU & IU \\
$1-18 y$ & 5,000 & 50,000 & $(1-6$ lakh $)$ & $600-1,000$ \\
old & IU & IU & IU & IU \\
$>18 y$ & 6,000 & 50,000 & $(1-6$ kakh $)$ & $1,500-2,000$ \\
old & IU & IU & IU & IU \\
\hline
\end{tabular}

During the treatment of vitamin $\mathrm{D}$, supplementation with calcium $(30-75 \mathrm{mg} / \mathrm{Kg})$ is recommended. Once serum PTH and $25(\mathrm{OH}) \mathrm{D}$, are normalized and vitamin D supplementation is reduced to $400 \mathrm{IU} /$ day, calcium supplementation is usually not necessary. ${ }^{61}$ However it is noteworthy to administer calcium intravenously (IV) under cardiac monitoring once hypocalcemia is associated with tetany and or hypocalcemic seizures. Usually calcium 
and phosphorus levels become normal within 6-10 days whereas PTH, 25(OH) D levels normalize within 1-2 months and serum alkaline phosphatase by 3-6 months. Complete radiological healing takes longer than one month although evidence of healing is seen within 4 weeks. It is recommended that 3 months after the treatment, serum levels of calcium, phosphorus, magnesium, serum alkaline phosphatase, $25(\mathrm{OH}) \mathrm{D}$ and $\mathrm{PTH}$, and $\mathrm{X}$ - ray if there are bone changes initially should be obtained. Subsequently $25(\mathrm{OH})$ D levels may be monitored yearly. ${ }^{61}$

\section{SCREENING OF VITAMIN D DEFICIENCY}

Age specific elevated levels of serum alkaline phosphatase is considered useful screening test ${ }^{62}$ followed by measurements of $25(\mathrm{OH}) \mathrm{D}$, calcium, phosphorus and PTH along with radiological examination of distal ends of radius and ulna or tibia and femur depending on the age. ${ }^{63}$ Alkaline phosphatase (ALP) levels are usually $500 \mathrm{IU} / \mathrm{L}$ and $1000 \mathrm{IU} / \mathrm{L}$ in neonates and children up to 9 years of age respectively. ${ }^{64}$ However some researchers believe that radiographic findings are more accurate than ALP since ALP is not raised in some vitamin $\mathrm{D}$ deficient rickety children. ${ }^{65}$

All those children should be screened who; ${ }^{34}$ a) have poor growth, gross motor delays, and unusual irritability; b) have chronic kidney disease or hepatic failure; c) have dark-skinned infants who live at higher latitudes in the winter and spring months; d) are on anticonvulsants or chronic glucocorticoids or ketaconazole; e) have chronic diseases that are associated with malabsorption; f) have BMI $>30 \mathrm{Kg} / \mathrm{m}^{2}$; g) have granulomatous diseases. ${ }^{18}$

\section{PREVENTION OF VITAMIN D DEFICIENCY}

Since sunlight is the principal source for the synthesis of vitamin $\mathrm{D}$, but other factors like dark skin, high latitude, winter months and $<10 \%$ the dietary sources ${ }^{66}$ makes vitamin D supplementation necessary. Exposure to sunlight for $30 \mathrm{~min} /$ week for infants in diaper and 2 hour/week for fully clothed infants without hat maintainsed vitamin $\mathrm{D}$ levels of $>11 \mathrm{ng} / \mathrm{dL}$. Dietary sources like oily fish and cod liver oil, liver and organ meat are rich natural sources of vitamin $\mathrm{D}$, but are not universally consumed by all due to cultural and food taboos, makes food fortification with vitamin D necessary ${ }^{67}$ Infants who consume exclusive breast feed and those who consume less than $1000 \mathrm{~mL}$ formula milk feed should be supplemented with $400 \mathrm{IU} /$ day of vitamin D. Preterm infants should be supplemented with 400-800 IU of vitamin D per day from birth. It is advisable to administer 3000-5000 IU/day of vitamin D to deficient mothers until their levels are $>20 \mathrm{ng} / \mathrm{dL}$, and it should be followed by $400 \mathrm{IU} /$ day ${ }^{68}$ However routine vitamin D supplementation to all pregnant mothers is controversial. ${ }^{69}$

\section{Standards of nutritional supplementation ${ }^{70}$}

Dietary Reference Intakes (DRIs) are reference values utilized for planning and assessing diets for healthy populations in various ways. The DRIs replace the revisions of the Recommended Dietary Allowances (RDAs). DRI envisages the Estimated Average Requirement (EAR), the Recommended Dietary Allowance (RDA), the Adequate Intake (AI), and the Tolerable Upper Intake Level (UL). The Estimated Average Requirement (EAR) is the nutrient intake value that is estimated to meet the requirement defined by a specified indicator of adequacy in 50 percent of the individuals in a life stage and gender group. At this level of intake, the remaining 50 percent of the specified group would not meet their nutrient needs. The Recommended Dietary Allowance (RDA) is the average daily dietary intake level that is sufficient to meet the nutrient requirements of nearly all (97 to 98 percent) individuals in a life stage and gender group. The EAR serves as the foundation for setting the RDA. The Adequate Intake (AI) is set instead of an RDA if sufficient scientific evidence is not available to calculate an EAR. The AI is based on observed or experimentally determined estimates of average nutrient intake by a group (or groups) of healthy people. The main intended use of the AI is as a goal for the nutrient intake of individuals. The Tolerable Upper Intake Level (UL) is the highest level of daily nutrient intake that is likely to pose no risks of adverse health effects to almost all individuals in the general population. As intake increases above the $\mathrm{UL}$, the risk of adverse effects increases. ${ }^{70}$

\section{Role of calcium supplementation}

The main role of vitamin $\mathrm{D}$ is to help calcium and phosphorus in our diet to be absorbed from the gut that are essential for optimal functioning and growth. Neonates and children with severe vitamin D deficiency can get muscle spasms, seizures, soft skull, poor growth, tooth eruption delay, bowed legs, irritability, and breathing difficulties due to low calcium levels secondary to hypovitaminosis D. ${ }^{9}$ So it seems prudent to supply calcium sufficient diet along with vitamin $\mathrm{D}$ for the optimal outcome.

\section{CONCLUSION}

It seems reasonable that mankind in general would be better served by a recommendation of higher daily intakes of vitamin $\mathrm{D}$, although latest research from the underdeveloped countries is yet to come. Till that time, balance of evidence weighs heavily for the simple and low-cost food fortification with vitamin $\mathrm{D}$ in daily consumables like cereals, milk, and salt. 


\section{REFERENCES}

1. Wacker M and Holick MF. Vitamin D - effects on skeletal and extra skeletal health and the need for supplementation. Nutrients 2013; 5: 111-148.

2. Gröber U, Jörg Spitz J, Reichrath J, Kisters K, and Holick MF. Vitamin D: Update 2013; From rickets prophylaxis to general preventive healthcare. Dermato-Endocrinology 2013; 5: e331-347.

3. Dijkstra SH, van Beek A, Janssen JW, de Vleeschouwer LH, Huysman WA, and van den Akker EL. High prevalence of vitamin $D$ deficiency in newborn infants of high risk mothers. Arch Dis Child 2007; 92: 750-753.

4. Ziegler EE, Hollis BW, Nelson SE, and Jeter JM. Vitamin D Deficiency in Breastfed Infants in lowa. Pediatrics 2006; 118; 603-660.

5. Christel JE, Lamberg-Allardt and Viljakainen HT. 25-Hydroxyvitamin $D$ and functional outcomes in adolescents. Am J Clin Nutr 2008; 88(suppl):534S-536S.

6. Rajakumar K. Vitamin D, cod-liver oil, sunlight, and rickets: a historical perspective. Pediatrics 2003; 112, e132-e135.

7. Hollis BW. Circulating 25-hydroxyvitamin D levels indicative of vitamin D sufficiency: implications for establishing a new effective dietary intake recommendation for vitamin D. J Nutr 2005; 135: 317-322.

8. Malabanan A, Veronikis IE and Holick MF. Redefining vitamin D insufficiency. Lancet 1998; 351: 805-806.

9. Brannon PM, Yetley EA, Bailey RL and Picciano MF. Overview of the conference "Vitamin D and Health in the 21st Century: an Update". Am J Clin Nutr 2008; 88(Suppl): 483S-490S.

10. Nykjaer A, Dragun D, Walther D, Vorum H, Jacobsen C, Herz J, et al. An endocytic pathway essential for renal uptake and activation of the steroid 25-(OH) vitamin D3. Cell 1999; 96: 507-515.

11. Norman AW, Ishizuka S, and Okamura WH. Ligands for the vitamin $D$ endocrine system: different shapes function as agonists and antagonists for genomic and rapid response receptors or as a ligand for the plasma vitamin $\mathrm{D}$ binding protein. J Steroid Biochem Mol Biol 2001; 76: 49-59.

12. Moe SM. Renal osteodystrophy. In: Pereira BJG, Sayegh MH, Blake P (ed). Chronic Kidney Disease, Dialysis, Transplantation. Elsevier, Saunders. Philadelphia, USA, 2nd ed., 2005; pp 136-157.

13. Zella LA, Shevde NK, Hollis BW, Cooke NE and Pike JW. Vitamin D-binding protein influences total circulating levels of 1 , $25-(\mathrm{OH}) 2 \mathrm{D} 3$ but does not directly modulate the bioactive levels of the hormone in vivo. Endocrinology 2008; 149: 3656-3567.

14. Dusso AS, Brown AJ and Slatopolsky E. Vitamin D. Am J Physiol Renal Physiol 2005; 289: F8-F28.

15. Rowling MJ, Kemmis CM, Taffany DA and Welsh J. Megalinmediated endocytosis of vitamin $\mathrm{D}$ binding protein correlates with 25-hydroxycholecalciferol actions in human mammary cells. J Nutr 2006; 136: 2754-2759.

16. Holick MF. Vitamin D deficiency. N Engl J Med 2007; 357:26622681.

17. Holick MF. Vitamin D for health and in chronic kidney disease. Semin Dial 2005; 18: 266-275.

18. Holick MF, Binkley NC, Bischoff-Ferrari HA, Gordon CM, Hanley DA, Heaney RP, et al. Evaluation, treatment, and prevention of vitamin D deficiency: an Endocrine Society clinical practice guideline. J Clin Endocrinol Metab 2011; 96:1911-1930.

19. Committee to Review Dietary Reference Intakes for Vitamin D and Calcium \& Institute of Medicine. Dietary Reference Intakes for Calcium and Vitamin D The National Academies Press, 2011.
20. Schöttker B, Haug U, Schomburg L, Köhrle J, Perna, L, Müller H, et al. Strong associations of 25 -hydroxyvitamin $D$ concentrations with all-cause, cardiovascular, cancer, and respiratory disease mortality in a large cohort study. Am J Clin Nutr 2013; 97:782-793.

21. Mohr SB, Gorham ED, Alcaraz JE, Kane Cl, Macera CA, Parsons JK, et al. Does the evidence for an inverse relationship between serum vitamin D status and breast cancer risk satisfy the Hill criteria? Dermatoendocrinol 2012; 4: 152-157.

22. Zittermann A, lodice S, Pilz S, Grant WB, Bagnardi $V$ and Gandini S. Vitamin D deficiency and mortality risk in the general population: a meta-analysis of prospective cohort studies. Am J Clin Nutr 2012; 95: 91-100.

23. Kazemi A, Sharifi $F$, Jafari $N$ and Mousavinasab N. High prevalence of vitamin $D$ deficiency among pregnant women and their newborns in an Iranian population. J Womens Health (Larchmt)2009;18:835-839.

24. Bener A, Al-Ali M and Hoffmann GF. High prevalence of vitamin D deficiency in young children in a highly sunny humid country: A global health problem. Minerva Pediatr 2009; 61: 15-22.

25. Kovacs CS. Vitamin D in pregnancy and lactation: maternal, fetal, and neonatal outcomes from human and animal studies. Am J Clin Nutr 2008; 88: 520S-528S.

26. Lapillonne $\mathrm{A}$. Vitamin $\mathrm{D}$ deficiency during pregnancy may impair maternal and fetal outcomes. Med Hypotheses 2010;74: 71-75.

27. Thandrayen $\mathrm{K}$ and Pettifor JM. Maternal vitamin D status: implications for the development of infantile nutritional rickets. Endocrinol Metab Clin North Am 2010; 39: 303-320.

28. Hollis BW and Pittard WB. Evaluation of the total fetomaternal vitamin $D$ relationships at term: evidence for racial differences. J Clin Endocrinol Metab 1984; 59: 652-657.

29. Hollis BW and Wagner CL. Assessment of dietary vitamin D requirements during pregnancy and lactation. Am J Clin Nutr 2004; 79: 717-726.

30. Hollis BW and Wagner CL. Nutritional vitamin D status during pregnancy: reasons for concern. CMAJ 2006; 174: 1287-1290.

31. Mannion C, Gray-Donald K and Koski K. Association of low intake of milk and vitamin $D$ during pregnancy with decreased birth weight. CMAJ 2006; 174: 1273-1277.

32. Sørensen IM, Joner G, Jenum PA, Eskild A, Torjesen PA and Stene LC. Maternal serum levels of 25-hydroxyvitamin D during pregnancy and risk of type 1 diabetes in the offspring. Diabetes 2012; 61:175-178.

33. Basile LA, Taylor SN, Wagner CL, Horst RL and Hollis BW. The effect of high-dose vitamin $D$ supplementation on serum vitamin $\mathrm{D}$ levels and milk calcium concentration in lactating women and their infants. Breastfeed Med 2006; 1:32-35.

34. Misra M, Pacaud D, Petryk A, Collett-Solberg PF and Kappy M. Drug and Therapeutics Committee of the Lawson Wilkins Pediatric Endocrine Society. Vitamin D deficiency in children and its management. Review of current knowledge and Recommendations. Pediatrics 2008; 122; 398-417.

35. Kreiter SR, Schwartz RP, Kirkman HN, Charlton PA, Calikoglu AS and Davenport ML. Nutritional rickets in African American breastfed infants. J Pediatr 2000; 137: 153-157.

36. Kreiter $S$. The reemergence of vitamin $D$ deficiency rickets: the need for vitamin D supplementation. AMB News Views Newsl 2001;7:1-5.

37. Greer FR. Issues in establishing vitamin D recommendations for infants and children. Am J Clin Nutr 2004; 80: 1759S-1762S.

38. Wagner CL and Greer FR. Prevention of Rickets and Vitamin D Deficiency in Infants, Children, and Adolescents. Pediatrics 2008;122: 1142-1153.

39. Looker AC, Dawson-Hughes B, Calvo MS, Gunter EW and Sahyoun NR. Serum 25-hydroxyvitamin D status of adolescents 
and adults in two seasonal subpopulations from NHANES III. Bone 2002; 30: 771-777.

40. Lapatsanis D, Moulas A, Cholevas V, Soukakos P, Papadopoulou Z and Challa A. Vitamin D: a necessity for children and adolescents in Greece. Calcif Tissue Int 2005; 77: 348-355.

41. Roth DE, Martz P, Yeo R, Prosser C, Bell M and Jones AB. Are national vitamin $D$ guidelines sufficient to maintain adequate blood levels in children? Can J Public Health 2005; 96: 443-449.

42. Palomer X, González-Clemente JM, Blanco-Vaca $F$ and Mauricio D. Role of vitamin $D$ in the pathogenesis of type 2 diabetes mellitus. Diabetes Obes Metab 2008; 10: 185-197.

43. Danescu LG, Levy S and Levy J. Vitamin D and diabetes mellitus. Endocrine 2009; 35: 11-17.

44. Pittas AG, Lau J, Hu FB and Dawson-Hughes B. The role of vitamin $D$ and calcium in type 2 diabetes. A systematic review and meta-analysis. J Clin Endocrinol Metab 2007; 92: 2017-2029.

45. Hyppönen $E$, Läärä $E$, Reunanen $A$, Järvelin $M R$ and Virtanen SM. Intake of vitamin D and risk of type 1 diabetes: a birth-cohort study. Lancet 2001; 358:1500-1503.

46. Zipitis CS and Akobeng AK. Vitamin D supplementation in early childhood and risk of type 1 diabetes: a systematic review and meta-analysis. Arch Dis Child 2008; 93:512-517.

47. Azab SF, Saleh SH, Elsaeed WF, Abdelsalam SM, Ali AA and Esh AM. Vitamin D status in diabetic Egyptian children and adolescents: a case-control study. Ital J Pediatr 2013; 39: 39-73.

48. Krobtrakulchai W, Praikanahok J, Visitsunthorn N, Vichyanond P, Manonukul K and Pratumvinit B. The Effect of Vitamin D Status on Pediatric Asthma at a University Hospital, Thailand. Allergy Asthma Immunol Res 2013; 5: 289-294.

49. Erkkola M, Kaila M, Nwaru BI, Kronberg-Kippilä C, Ahonen S, Nevalainen $\mathrm{J}$, et al. Maternal vitamin D intake during pregnancy is inversely associated with asthma and allergic rhinitis in 5-yearold children. Clin Exp Allergy 2009; 39: 875-882.

50. Weisse K, Winkler S, Hirche F, Herberth G, Hinz D, Bauer M, et al. Maternal and newborn vitamin $D$ status and its impact on food allergy development in the German LINA cohort study. Allergy 2013; 68: 220-228.

51. Bergman $P$, Lindh $A U$, Björkhem-Bergman $L$ and Lindh JD. Vitamin $D$ and respiratory tract infections: A systematic review and meta-analysis of randomized controlled trials. PLoS One 2013; 8: e658-e635.

52. Ginde AA, Mansbach JM and Camargo CA. Association between serum 25-hydroxyvitamin $D$ level and upper respiratory tract infection in the Third National Health and Nutrition Examination Survey. Arch Intern Med 2009; 169: 384-390.

53. Camargo CA, Ganmaa D, Frazier AL, Kirchberg FF, Stuart JJ and Kleinman K, et al. Randomized trial of vitamin D supplementation and risk of acute respiratory infection in Mongolia. Pediatrics 2012; 130: e561-567.

54. Dong $Y$, Stallmann-Jorgensen IS, Pollock NK, Harris RA, Keeton D, Huang Y, et al. A 16-week randomized clinical trial of 2000 international units daily vitamin D3 supplementation in black youth: 25-hydroxyvitamin D, adiposity, and arterial stiffness. J Clin Endocrinol Metab 2010; 95: 4584-4589.

55. Shedeed SA. Vitamin D supplementation in infants with chronic congestive heart failure. Pediatr Cardiol 2012; 33: 713-719.

56. Ross AC, Manson JE, Abrams SA, Aloia JF, Brannon PM, Clinton SK, et al. The 2011 report on dietary reference intakes for calcium and vitamin D from the Institute Of Medicine: What clinicians need to know? J Clin Endocrinol Metab 2011; 96:53-58.

57. Hollick FM. Resurrection of rickets vitamin D deficiency and rickets. J Clin Invest 2006; 116: 2062-2072.

58. Wagner $\mathrm{CL}$ and Greer FR, for the American Academy of Pediatrics Section on Breastfeeding; American Academy of Pediatrics Committee on Nutrition. Prevention of rickets and vitamin $\mathrm{D}$ deficiency in infants, children, and adolescents [published correction appears in Pediatrics. 2009; 123: 197]. Pediatrics 2008; 122: 1142-1152.

59. Alagöl $F$, Shihadeh $Y$, Boztepe $H$, Tankol R, Yarman $S$, and Azizlerli $\mathrm{H}$. Sunlight exposure and vitamin $\mathrm{D}$ deficiency in Turkish women. J Endocrinol Invest 2000; 23: 173-177.

60. Gordon CM, Williams AL, Feldman HA, May J, Sinclair L, Vasquez A, et al. Treatment of hypovitaminosis $D$ in infants and toddlers. J Clin Endocrinol Metab 2008; 93: 2716-2722.

61. Balasubramanian S, Dhanalakshimi $\mathrm{K}$ and Amperayani $\mathrm{S}$. Vitamin D Deficiency in Childhood - A Review of Current Guidelines on Diagnosis and Management. Indian Pediatr 2013; 50: 669-675.

62. Joiner TA, Foster $\mathrm{C}$ and Shope $\mathrm{T}$. The many faces of vitamin $\mathrm{D}$ deficiency rickets. Pediatr Rev 2000; 21: 296.

63. Spence JT and Serwint JR. Secondary prevention of vitamin D deficiency rickets. Pediatrics 2004; 113: e70-e72.

64. Wharton B and Bishop N. Rickets. Lancet 2003; 362: 1389-1400.

65. Pettifor JM, Isdale JM, Sahakian J and Hansen JD. Diagnosis of subclinical rickets. Arch Dis Child 1980; 55: 155-157.

66. Kaushal $\mathrm{M}$ and Magon N. Vitamin $\mathrm{D}$ in pregnancy: A metabolic outlook. Indian J Endocrinol Metab 2013; 17: 76-82.

67. Lamberg-Allardt C. Vitamin $D$ in foods and as supplements. Prog Biophys Mol Biol 2006; 92: 33-38.

68. Working Group of the Australian and New Zealand Bone and Mineral Society, Endocrine Society of Australia and Osteoporosis Australia. Vitamin D and adult bone health in Australia and New Zealand: a position statement. Med J Aust 2005; 182: 281-285.

69. Thomson K, Morley R, Grover SR and Zacharin MR. Postnatal evaluation of vitamin $D$ and bone health in women who were vitamin -D deficient in pregnancy, and their infants. Med J Aust 2004; 181: 486-488.

70. Dietary Reference Intakes for Calcium, Phosphorus, Magnesium, Vitamin D, and Fluoride. http://www.nap.edu/catalog/5776. pp 1-5. accessed on 06.05.2015

\footnotetext{
Authors Contribution:

MA - Conceived the study, analyzed the data, drafted \& finalized the manuscript; Mls - Contributed to the study design and final draft; NAP and MIr - Collected data \& reviewed the manuscript, KA - Reviewed the manuscript.
}

Source of Support: Nil, Conflict of Interest: None declared. 